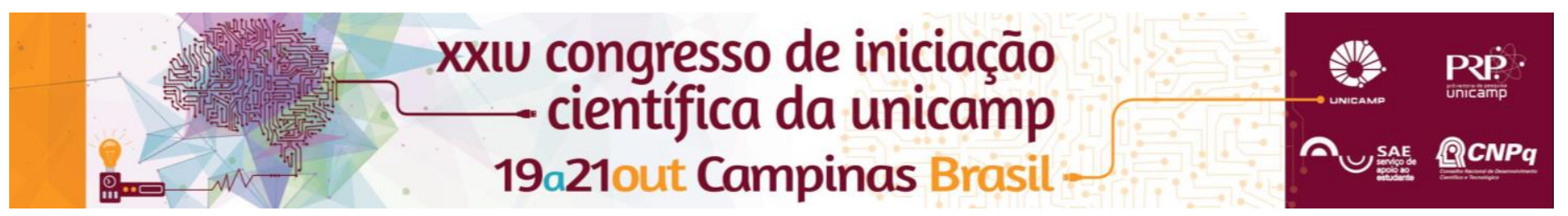

\title{
Os efeitos da crise financeira sobre o setor externo dos países do BRICS
}

\author{
Vinicius G. Morello*, Bruno M. de Conti.
}

\section{Resumo}

Com a eclosão da crise financeira mundial em 2007/08, iniciou-se um período de retração econômica caracterizada por queda do PIB mundial e diminuição do nível de comércio. A recuperação posterior ocorre de forma mais rápida nos países emergentes. Assim, o objetivo deste trabalho é analisar os efeitos da crise financeira sobre o setor externo dos países do grupo político "BRICS", formado por Brasil, Rússia, Índia, China e África do Sul, países emergentes de grande população, território e influência econômica, países que passavam por rápida expansão econômica no momento anterior à crise. Para a realização do trabalho, foram feitas análises dos balanços de pagamentos de cada país, com foco no saldo da balança comercial, conta financeira e na variação de reservas. Resultados mostram que, em geral, os países do BRICS sofreram mais com o colapso do comércio internacional, marcado pela retração das importações e exportações, que acabou por gerar impacto bastante significativo no PIB. Os efeitos da crise foram diferentes para cada um dos países do grupo, tendo a Rússia sentido os efeitos da crise de forma mais intensa.

\section{Palavras-chave:}

BRICS, crise financeira, setor externo.

\section{Introdução}

No ano de 2007, teve início a crise no mercado americano dos créditos subprimes, primeiramente com abrangência restrita, mas que, após a falência do banco de desenvolvimento Lehman Brothers, se espalhou globalmente, tornando-se uma crise multidimensional, com impactos profundos sobre toda a economia mundial, incluindo países periféricos ${ }^{1}$.

Inicia-se um período de retração econômica global a partir de setembro de 2008 e o PIB mundial chega a ter um decréscimo no ano de 2009. A recuperação a nível mundial entre 2009 e 2010 se deu a passos lentos, mas foi muito mais expressiva nos países emergentes do que nas grandes economias centrais ${ }^{2}$.

Tendo em vista esta divergência na recuperação entre países emergentes e centrais, o objetivo deste trabalho é analisar os efeitos da crise sobre o setor externo dos países do BRICS, buscando determinar as especificidades de cada país através de análise das contas do balanço de pagamentos, verificando os saldos comerciais de cada país, os fluxos de investimento externo, as remessas de lucro para o exterior e variações no total de reservas, entre outros.

\section{Resultados e Discussão}

O período selecionado para estudo foi do ano 2000 ao ano de 2013. A escolha deste período permite a comparação entre o período pré-crise, de grande crescimento econômico mundial (2000 a 2007), e o período posterior (2008 a 2013), quando os efeitos da crise foram sentidos em todo o mundo.

Em relação ao saldo da balança comercial, em valor, houve uma piora significativa no período posterior a crise. A recuperação para níveis pré-crise - quando ocorre - se dá de forma rápida e passageira. As razões para esta queda estão, no desaquecimento da economia global em especial dos países centrais -, que leva a uma queda na demanda externa por exportações, na queda do preço DOI: 10.19146/pibic-2016-50932 de commodities e nas variações cambiais ${ }^{3}$. Além disso, há queda da participação dos saldos comerciais no PIB, em especial após 2011.

Em relação ao fluxo de capitais, o que se nota no período após a eclosão da crise é um aumento dos fluxos de IDE em direção aos BRICS, mais aquecidos que a maioria das economias centrais - apesar da crise - atraindo investidores. As exceções são África do Sul e Rússia.

Em relação as reservas internacionais, as quedas após a eclosão da crise foram substanciais em todos os países, resultado do esforço de contenção da crise e financiamento de déficits em transações correntes.

\section{Conclusões}

Os efeitos da crise sobre o setor externo dos BRICS foram mais graves do que o que se supõe, mas, na maioria dos casos, mais ameno do que nas economias centrais. A curto prazo, os efeitos tiveram mais relação com o desaquecimento da economia global e queda no preço de commodities. Certamente as políticas governamentais de resposta tiveram papel fundamental para a rápida recuperação que se seguiu já a partir de 2010 A longo prazo, a crise evidencia a fragilidade e situação de extrema dependência dos BRICS com relação a uma balança comercial favorável e ao fluxo constante de capitais financeiros internacionais, responsáveis em grande parte pelo financiamento dos eventuais déficits em transações correntes.

\section{Agradecimentos}

Agradeço ao PIBIC/CNPq pelo financiamento, amigos, família e meu orientador - Bruno - pelo apoio.

\footnotetext{
1 Baldwin, R. E. The Great Trade Collapse: Causes, Consequences and Prospects. CEPR, 2009.

2 Biancarelli, A. Uma nova realidade do setor externo brasileiro, em meio à crise internacional. Textos para discussão, Rede Desenvolvimentista, 2012

${ }^{3}$ Fundap. A forte deterioração das transações correntes e da balança comercial em 2013. Boletim de Economia - Conjuntura Econômica em Foco, v. 25, p. 5 11 , out. 2013
} 